\title{
FORENSIC CASE FILES
}

Diagnosing and Treating the Pathologies of the American Health System 
This page intentionally left blank 


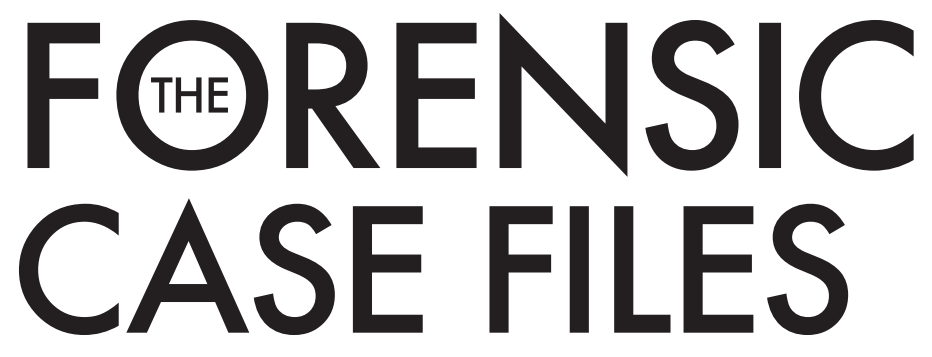

\section{Diagnusing and Treating the Pathologies of the American Health System}

\section{David Barton Smith}




\section{Published by}

World Scientific Publishing Co. Pte. Ltd.

5 Toh Tuck Link, Singapore 596224

USA office: 27 Warren Street, Suite 401-402, Hackensack, NJ 07601

UK office: 57 Shelton Street, Covent Garden, London WC2H 9HE

\section{British Library Cataloguing-in-Publication Data}

A catalogue record for this book is available from the British Library.

\section{THE FORENSIC CASE FILES}

Diagnosing and Treating the Pathologies of the American Health System

Copyright (c) 2010 by World Scientific Publishing Co. Pte. Ltd.

All rights reserved. This book, or parts thereof, may not be reproduced in any form or by any means, electronic or mechanical, including photocopying, recording or any information storage and retrieval system now known or to be invented, without written permission from the Publisher.

For photocopying of material in this volume, please pay a copying fee through the Copyright Clearance Center, Inc., 222 Rosewood Drive, Danvers, MA 01923, USA. In this case permission to photocopy is not required from the publisher.

ISBN-13 978-981-283-837-7

ISBN-10 981-283-837-6

Typeset by Stallion Press

Email: enquiries@stallionpress.com

Printed in Singapore. 


\title{
Dedication
}

\author{
To my students who have been my teachers
}


This page intentionally left blank 


\section{Preface}

As this book goes to press, the pathologies of the American health system and the prescriptions for their treatment are the focus of a heated national debate and pending legislation. The cases presented in this book provide stark, concrete examples of the underlying barriers that make healthcare reform so essential yet frustratingly difficult. These barriers include how the American healthcare system is governed, its physicians organized, nursing care provided, its services paid for, its market works and how all of it is regulated.

I started writing The Forensic Case Files with the aim to assist those within the United States healthcare system in understanding the underlying problems so they could address them. It became clear that they need a lot of help. I ended up writing for a broader audience for two reasons.

First, the American public owns their health system. They own it through the taxes they pay, the benefits they purchase through employment and the special tax exemptions and subsidies they provide to assure decent care. It is not owned by private insurance plans, hospital chains, or pharmaceutical corporations any more than the armed forces are owned by defense contractors. The special dispensations to non-profit "private" health plans and health systems make them an arm of the state, in essence owned by the public. The issue is not about "government takeovers" or a battle to preserve "free markets." The issue is how the American public wants to govern their health system. Its pathologies result from the absentee ownership vacuum that has been filled by special interests. It is time the public owners stopped being absentee ones. 
Second, the public owners of the health system must now ask a critical moral question. Should everyone just take care of themselves or should we look after each other? Most Americans would lean towards the "we should look after each other" answer to this question but how this should be done is the focus of the current debate. Most of the cases in this book describe the troubling consequences of private market approaches to "taking care of each other" that too few have paid attention to.

Writing the cases in this book about the pathologies in the American health system was both exhilarating and uncomfortable. The stories had twists and turns that I had never thought about before. It was also an opportunity, with the unique freedom only afforded at the end of one's career, to tell the truth about the most complex, troubling and intractable problem faced in the United States. Yet, it was difficult to find a balance between the admiration and affection I feel for those who work in healthcare and the discouraging pathologies of the system within which they work. In some of the revelations in this book I felt I was being disloyal. I can only hope that the effort to reveal the truth is the ultimate form of loyalty and the path to correction of the pathologies, but it is uncomfortable.

I have accumulated a lot of debts in pulling these stories together. The result is a collective distillation of so many people that it is impossible to acknowledge them all here. While the flaws are mine alone, whatever redeeming values this book has is a reflection of their collective influence.

The more than 1,000 students in healthcare careers that I have worked with in the Cornell University Sloan Program in Healthcare Management, the University of Rochester Community Medicine Department, the Healthcare Management program in the business school at Temple University and in the Drexel University School of Public Health have served as my teachers and sources of many of the pieces of the stories presented here. They are acknowledged in the dedication of this book. I hope that their efforts to educate me, as reflected in the cases in this book, will be of assistance to those now entering healthcare careers.

Colleagues have played a critical role in shaping the ideas in this book. These include Roger Battistella and John Kuder at Cornell, William Barker, Ernest Saward and Bob Berg at the University of Rochester Community Medicine Department, and long time friend and co-author Arnold Kaluzny at the Cecil G. Sheps Center for Health Services Research at the University 
of North Carolina. I am deeply indebted to my colleagues at Temple University, particularly those in the Risk, Insurance and Healthcare Management Department, Bill Aaronson, Tom Getzen, Chuck Hall and Jacqueline Zinn where I spent the bulk of my career. More recent collaborators have included Dennis Andrulis at the Drexel University School of Public Health's Center for Health Equality, Zhanlian Feng, Vince Mor and Mary Fennell at the Center for Gerontology and Health Services Research at Brown University and Mary Jane Koren at the Commonwealth Fund. Early influences included a remarkable group of pioneering researchers and healthcare reformers who guided me as a doctoral student in The University of Michigan's program in Medical Organization - Solomon J. Axelrod, Avedis Donabedian, Gene Feingold and Charles Metzner.

This book provided the opportunity to revisit joint efforts of the past to which many contributed. These included a book on the regulation of nursing homes supported by a grant from what is now the Agency for Healthcare Research and Quality and published by Health Administration Press, a book on the racial integration of healthcare supported by a grant from the Robert Wood Johnson Foundation and published by The University of Michigan Press, work on allied health workforce supply and demand in the Philadelphia area and in Pennsylvania supported by the Pennsylvania Center for Health Careers of the Workforce Investment Board with the assistance of Bill Aaronson at Temple University and a health assessment for the Pottstown Health and Wellness Foundation done in collaboration with DGA Partners, with the assistance of John Harris. I am also indebted to the Temple University Heart Transplant Team, particularly Jack Kolff, director of the program at the time and the Gift of Life Donor Program and its director Howard Nathan for their assistance in providing me the opportunity to observe and learn from their efforts.

Investigative reporters and the newspapers that support them troll the same waters as academic researchers but are so much better at catching the big fish and providing the richness in detail. I am indebted, as we all are to their efforts, so critical for a democracy. Two such talented efforts were particularly helpful in fleshing out several of the cases in this book: Steve Massey's series in the Pittsburgh Post-Gazette on the AHERF bankruptcy and John Shiftman's series in the Philadelphia Inquirer on the investigation of Akhil Bansal's illegal internet prescription network. 
In helping with the heavy lifting in preparing this manuscript, I am indebted to many. Dennis Andrulis, Richie Kahn, Ray Lum, Robert Pickard and Jonathan Purtle at Drexel University's School of Public Health provided very helpful comments on portions of the manuscript. Judy Harrington, Vice President at Health Partners provided a particularly useful guidance on the AHERF and HealthChoices cases. Long time friend and colleague Bob Uris crafted the U.S. Healthcare case. I am particularly indebted to a comprehensive review by Joel Telles, Systems Director, Data Management and Analysis at Main Line Health on the entire manuscript. All of his thoughtful suggestions were not possible to include in this manuscript but perhaps several new books will be in the offing. Granddaughter Shannon Eaton, sociologist in training at the University of Maryland, provided encouragement and useful suggestions. I am deeply grateful to Mary Ellen Cook at the Center for Health Equality at Drexel who added to her many duties the tracking down of permissions. I am also indebted to Deborah Ruth Hoffman of Swarthmore who with a very tight deadline expertly handled the initial editing of a very rough manuscript before it was sent to the publisher. On the other side of the world, V.K. Sanjeed of Singapore also expertly handled the editing and final proof preparation for World Scientific Publishing.

As with previous books, my wife, Joan K. Apt reviewed all the chapters and assisted with the preparation of the index with the useful commentary of an experienced and skeptical healthcare manager but supportive helpmate. I have indeed been fortunate. I can only hope that our youngest son, Alex, now entering the doctoral program in Economics at the University of Virginia will be as fortunate. 


\section{Contents}

Dedication v v

Preface vii

Chapter 1 Introduction: Fixing Healthcare 1 in the United States

Chapter 2 Governance: Who's in Charge? 9

Organizing the Owners 9

Case 1: HealthEast and the Misplaced Mission 13 of a Voluntary System

Case 2: The AHERF Bankruptcy: Failure 19 of Board Oversight

Chapter 3 The Medical Staff: Villains or Victims? 33

Organizing the Medical Staff 33

Case 3: The Mysterious Death of a Mobile $\quad 37$ Infirmary Medical Staff Member

Case 4: South Park Hospital and the Limits of Medical Staff Oversight 
Chapter 4 Nursing: Where Is It Going and Why Does

It Never Get There?

Nursing's Stunted Evolution

Case 5: Why Did Franklin Go Bankrupt?

Case 6: How Should Healthcare Organizations Respond to the Nursing "Shortage"

Chapter 5 Financing: How Gold Rules

Following the Money

Case 7: Len Abramson and U.S. Healthcare — By Robert Uris

Case 8: The Office of Medical Assistance and HealthChoices

Chapter 6 The Market: Why It Doesn't Work -

Or Does It?

Working the Market

Case 9: Concierge Medicine

Case 10: Barix Clinics: The Case of the Focused Fat Factory

Case 11: The Gift of the Heart

Chapter 7 Forecasting Trends and Repackaging the Future

Repackaging Care

Case 12: Globalization, Bansal and the Internet Prescription Bust

Case 13: Aging, Klaassen and the Killer 
Chapter 8 Diagnosing and Treating the Pathologies of the U.S. Health System

Recurring Themes 147

Case 14: Pottstown Hospital's Conversion 148 Foundation

Case 15: State and Federal Healthcare Reform 158 Initiatives: From Rendell to Obama

Final Postscript

172

About The Author

175

Bibliography

Index 